\title{
OLD GEOPHYSICAL DATA APPLIED TO MODERN GEOLOGICAL MAPPING PROBLEMS: A CASE-STUDY IN THE SERIDÓ BELT, NE BRAZIL
}

\author{
ELTON LUIZ DANTAS ${ }^{1}$, ADALENE MOREIRA SILVA ${ }^{2}$, TATI ALMEIDA ${ }^{3} \&$ \\ ROBERTO ALEXANDRE VITÓRIA DE MORAES ${ }^{1}$
}

\begin{abstract}
The Seridó belt, northeast Brazil, is a Brasiliano-Pan-African collisional orogen formed between the West African, São Francisco and Amazon cratons during the west Gondwana assemblage. This area is an excellent example for illustrating the usefulness of gamma-ray spectrometric data to support modern geological mapping in semi-arid terranes. Analyses of $\mathrm{K}$, Th and $\mathrm{U}$ channels images, displayed as composite themes, correlate well with the main regional framework of the Seridó Belt. Several distinct mapped units are easily distinguishable in the gamma-ray spectrometric data, as the Paleoproterozoic basement rocks and the supracrustal metasedimentary sequences of the Neoproterozoic Seridó Group. Also, the granitic plutons and the Phanerozoic cover show different geophysical signatures. Definition of contacts among units, faults, folds and shapes of granitic intrusions are considerably enhanced by the airborne gammaray spectrometry data. The results here presented show that there is a strong relationship among geochemical, isotopic and geophysical signatures of different crustal blocks recognized in the region. This kind of approach seems fundamental for investigating regional crustal evolution in overly complex deformed Precambrian areas. It also can be of some help to better define the boundaries of the different lithostratigraphic units that could appear in similar orogenic belts within the Brazilian Shield.
\end{abstract}

Key-words: Seridó Belt, modern geological mapping, airborne gamma-ray spectrometry data, semi-arid terranes.

INTRODUCTION Airborne gamma-ray spectrometric data are often used as a powerful tool to aid both mineral exploration and lithological mapping. Many times, there is a good correlation between patterns in the radiometric data and non-weathered rocks or in areas of poor outcrops (Gunn et al. 1997, Golysnky \& Jacobs 2001). A few papers in Brazil have been published using integrated geophysical and geologic mapping techniques, which is an underrating on how this tool can be important and helpful in understanding complex Precambrian terranes (Silva 1999, Blum 1999, Costa et al 2002, Oliveira et al. 2001).

Airborne geophysical surveys have been carried out in Brazil since 1952 (Mourão, written communication). However, only within the last two decades have this data been established as a powerful tool in geological mapping (Reeves 1997). On regional scale airborne geophysical data have often been used to identify several features, such as: limits of geologic provinces, fold belts, sedimentary basin and tectonic and structural detail of shear zones and overprinted structural trends (Schetselaar 2001, Direen et al. 2001).

The aim of this paper is to present the results of qualitative processing enhancement, and interpretation of the radiometric data previously collected in the Serido region. This region is characterized by a plethora of fresh to moderately weathered bedrock, owing to the semi-arid climate of NE Brazil, having many outcrops and well-defined lithologic and stratigraphic contacts among them. Also, the Seridó belt becomes a interesting example to apply geophysical methods in geological mapping problems, because it is characterized by a complex tectonic history, developed during the interference between different orogenic cycles, where superposed structural phases are generated (Jardim de Sá 1994, Araújo et al. 2002). Another important point is the large diversity of individualized rocks present in this area, involving basement gneissic rocks, supracrustal sequences, granite plutons and small sedimentary basin covers.

The main goal to meet here is to integrate airborne data with field mapped geological units information, several of which have also been dated by modern geochronological techniques. In order to achieve this goal, the approach was to start with a well known geologically mapped and understood area, and compare the geology with the processed radiometric data to check the indications pointed out by the geophysical signatures. To accomplish this a thorough examination was done on the geophysical data along with field and laboratory checks, to explore detailed features and to define patterns that may prove useful in pursuing further applications on similar but less well-known Precambrian areas.

THE DATA SET The Seridó geophysical data set was obtained in 1973 from the Projeto Seridó flown by LASA - Engenharia e Prospecções S. A., under contract with CPRM (Brazilian Geological Survey), and on behalf of the Brazilian Governmental Agencies DNPM (National Mineral Production Department) and CNEN (Nuclear Energy National Council). The survey comprised 28,000 line kilometers of profiles, sampling the magnetic field intensity and

1 - Universidade de Brasília, Instituto de Geociëncias, Brazil, elton@unb.br

2 - Universidade Estadual de Campinas;Brazil

3 - Exército Brasileiro, COTER, Centro de Sensoriamento Remoto. 
the gamma-ray spectrum of the natural emissive elements, covering an area of $25,000 \mathrm{~km}^{2}$ (CPRM 1995). The radiometric data are measured with an Exploranium ${ }^{\mathrm{TM}}$ model DGRS-2000 spectrometer, using 1.012,5 cubic inches of $\mathrm{NaI}(\mathrm{Tl})$ (sodium iodide thallium activated) detector crystal using 2 seconds of integration time. This differential spectrometer furnished the readings of four discriminated spectral windows, corresponding to total count (covering from 0.76 to 2.81 millions of electron-Volts or $\mathrm{MeV}$ ), potassium through $\mathrm{K}^{40}$ (1.37 to $\left.1.57 \mathrm{MeV}\right)$, uranium through $\mathrm{Bi}^{214}$ (1.66 to $1.86 \mathrm{MeV}$ ) and thorium through $\mathrm{Tl}^{208}(2.41$ to $2.81 \mathrm{MeV})$ recorded digitally and analogically on board. Unfortunately CPRM could not retrieve any of the original digital data and the data used here were recovered from digitalization of plotted analog stacked profiles. This work was done by Paterson, Grant \& Watson Limited (PGW, Canada) as part of the Brazil Airborne Radiometric Mapping Project - BARMP using throughout back-calibration technique. One of the uranium channel maps (sheet SB.24-Z-B-III-1) was lost and the corresponding digitalized $\mathrm{XYZ}$ data is missing in the used dataset (Mourão, written communication). The E-W flight lines were flown with 1,000 meters interval, crossed by $\mathrm{N}-\mathrm{S}$ tie lines flown at every 20,000 meters. Sampling was carried out using draped flights at a nominal clearance of 135 meters. Visual navigation was used throughout, performed on semi-controlled photomosaics. The recovery of flight path was done from $35 \mathrm{~mm}$ flight track camera film on same photomosaic bases.

REGIONAL GEOLOGIC SETTING The geological framework of the central part of Borborema Province (BP) in NE Brazil includes several Meso to Neoproterozoic supracrustal sequences overlying Archean to Paleoproterozoic basement complexes. They were intruded by a large number of granitic plutons ca. $600 \mathrm{Ma}$ ago (Fig. 1). Geodynamical evolution models for the region suggest a complex evolutionary history, which include the accretion of different tectonic-stratigraphic terrenes during the Neoproterozoic orogenic collage (Van Schmus et al. 1995, Jardim de Sá 1994, Castro et al. 1998). The basement of the BP is characterized by orthogneisses and granitoids intruded and metamorphosed during the Paleoproterozoic cycle (2.2 to $1.9 \mathrm{Ga})$. These granitoids represent $30 \%$ of the exposed BP rocks. They show a common geological evolution defining a single Paleoproterozoic crustal block in the central part of the province, called the Rio Grande do Norte Terrane (RGNT of Santos et al. 1999).

Interpretation of a gravity survey led Castro et al. (1998) and Gusmão et al. (2001) to the identification of a complex pattern of anomalies in the RGNT, suggesting that this geotectonic unit is composed of distinct tectonic-stratigraphic terranes, bounded by large-scale shear zones. The structures reflect the boundaries of these separated terrenes or collisional sutures, such as the lithospheric discontinuities, as the Patos Lineament, a remarkable mylonitic E-W trending shear zone system.

The basement rocks are represented mainly by Paleoproterozoic reworked crust, dated at 2.2 to $2.15 \mathrm{Ga}$ (U-Pb zircon ages, Hackspacher et al. 1990), involving a wide range of granitoids with composition varying from tonalite to granite. The rocks were deformed under amphibolite facies conditions and late, overprinted by a greenschist facies metamorphic event. $\mathrm{Nd}$ isotopic dating on basement rocks suggests a dominantly Archean source for the generation of the granitoid protoliths (Van Schmus et al. 1995, Dantas et al. 2000).

The Serido fold belt comprises the central NE-trending schist belt in the northern part of the Borborema Province (Fig. 1). This supracrustal metasedimentary sequence includes an upper unit composed of metapelites, biotite-muscovite-schist and biotite gneiss (Seridó Formation). An intermediary unit is represented mainly by quartzite and conglomerate (Equador Formation). The basal unit is an association of epidote gneiss, marble and small amount of metavolcanic mafic rocks, represented by amphibolite bodies 1-100 meters thick (Jucurutu Formation). A transpressional deformational domain is associated to the central part of the Seridó Belt, were NE trending dextral strike-slip shear zones and large scale open folds are the most common feature developed during this event. A transtensional /extensional deformational domain is evident in the westernmost part of the Seridó belt (Archanjo et al. 1998). Hydrothermal phases are developed associated to the strike slip shear zones, occurring small Au mineralization near Caicó.

A large number of syntectonic intrusive Brasiliano granites were emplaced associated with the strike slip shear zones. The magmatism ranges from dominant calc-alkaline monzogranites to a minor amount of alkaline-rich mafic rocks, mainly diorites.

Aeromagnetic data from the Seridó region were processed by Souza (2000) and Oliveira (2001), revealing linear anomalies that correspond to the main shear zone systems that separating different litho-stratigraphic terranes. Souza (2000) determined two major magnetic domains in the total magnetic field and localized high magnetic anomalies in the Afonso Bezerra and Santa Luzia regions.

DATA PROCESSING Initial processing involved flight line editing for bad records. This was followed by interpolation where the irregularly spaced line data were distributed at the corners of 500-meter square grid cells, using a minimum curvature algorithm (Briggs 1974). This procedure allowed for immediate application of the proposed enhancement techniques. Also the original positioning in Equatorial Mercator projection was further converted to Universal Transverse Mercator, Zone 24 /25.

The grids of each gamma-ray spectrometric channel were then microleveled (Minty 1991) using a routine developed by Blum (1999) for the Laboratory of Applied Geophysics (LGA) of Universidade de Brasília. The algorithm filters out any apparent residual error remaining from the application of the standard survey grid (macro) leveling techniques. The microleveling corrects the small discrepancies and spatially homogenizes the data making possible the generation of a better image from the gridded data (see Blum 1999, Silva 1999, for further details). In spite of all these efforts, some artifacts could not be removed due to the very nature of the digitalized data. Finally, some redatuming of the radiometric data was found necessary to avoid negative values.

\section{DATAINTERPRETATIONANDINTEGRATIONFORMODERN} GEOLOGICAL MAPPING The main goal of this paper is to understand what kind of regional features could be identified from geophysical data obtained three decades ago, and how to access its potential to solve actual geological problems. It was seen that processing these old data could really help in the interpretation of complex Precambrian terranes, specially in areas were the outcrops are rare or limited. Display options of airborne data may include tradional methods (stacked or simple profile plots, and contour maps) and, frequently, raster images of single channel or several types of combination.

In general, the first step in the analysis and intepretation of radiometric data consistes of a visual interpretation of the single channel information, folowed by analysis of the composite maps. Another approach is to use instead composition techniques such 

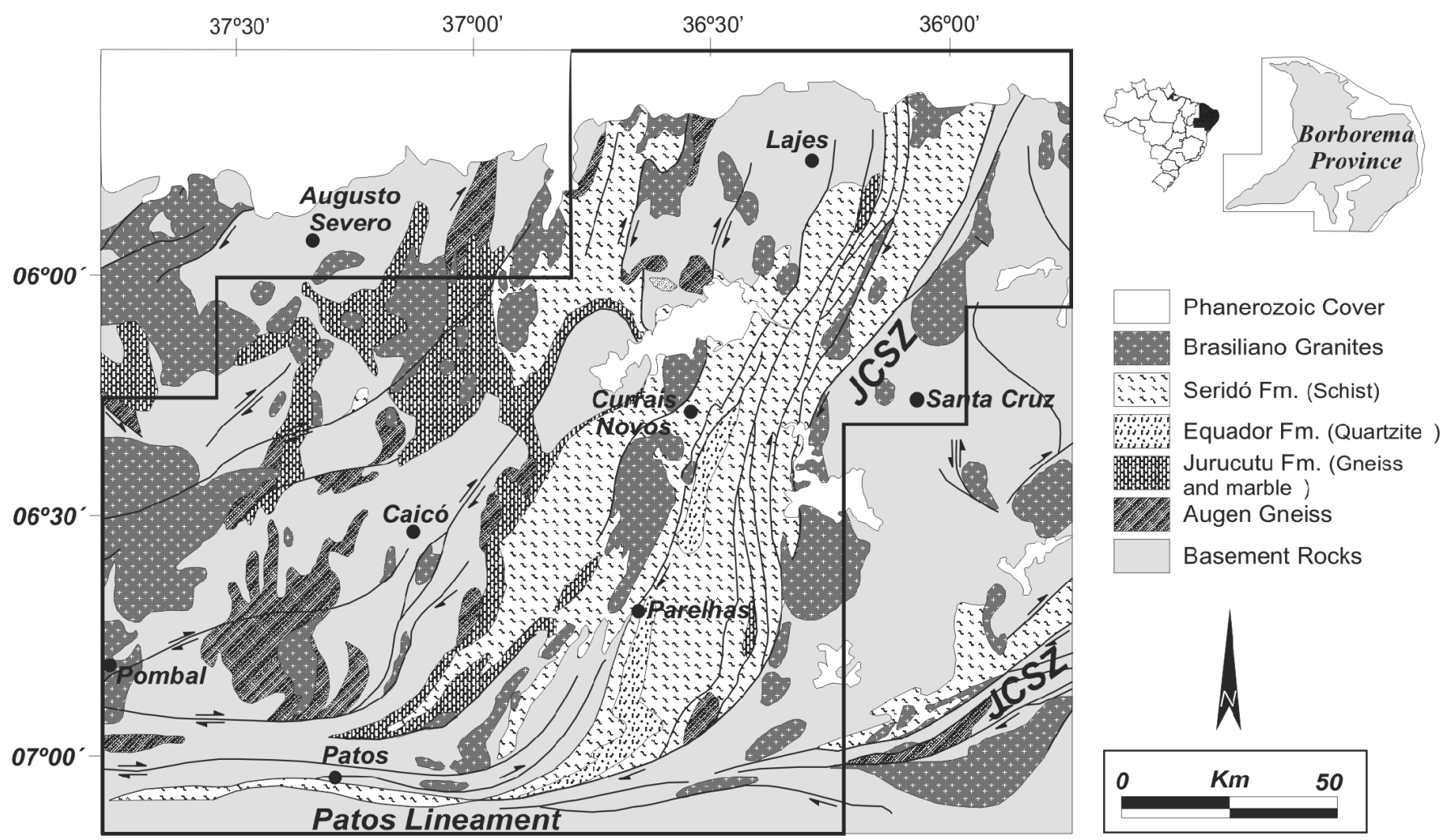

Figure 1 - Geological map from the Seridó Belt, showing the main unities and structures present in the region, modified from Jardim de Sá (1994). The limits of the aerogeophysical survey studied here, is enhanced in the figure. JCSZ-João Câmara Shear Zone.

as RBG, CMY, RBG inverted and/or CMY inverted. RBG composition was used here since it showed the best visual correlation with the geologic features in the studied area.

The RBG colour composite uses an additive combination on red, green and blue (primary colours). To accomplish this, the three gamma-ray spectrometric grids with the resultant values for potassium, thorium and uranium were individually enhanced, as a function of their individual stochastic distribution (histograms), and then summed up in a process similar to what happens in a typical color TV screen tube, and displayed as pseudocolor. Thus, to the potassium, thorium and uranium enhanced values for each theme were assigned different color shades of red, green and blue, respectively, to create a composite RGB color model. The aim was to use these data by defining if a spatial correlation exists between the radiometric data and the mapped lithological units.

The generated products from the gamma-ray spectometry data showed good correlation with the known geological maps, mainly with the identification of the regional litological units (Fig. 1). The resolution achieved for the gamma ray data after microleveling, allowed to reveal the major tectonic domains and litological units present in the Seridó region (Figs. 2, 3 and 4), as the Phanerozoic cover (A), Neoproterozoic metasedimentary sequences (B), Paleoproterozoic basement rocks (C) and granitoid bodies (D).

However, the second order magnitude anomalies are probably the most important aspect like to emphastize in this study. They show contrasting features in the inner basement rocks of the Caicó region. They also show that the basement presents complex radiometric signatures, complying with the fact that it is composed of differentiated plutonic rocks as evidenced by $\mathrm{U} / \mathrm{Pb}$ zircon crystallization ages of $2.15 \mathrm{Ga}$ (Hackspacher et al. 1990). The composition of these orthogneisses ranges from gabbroic to granitic, with predominance of tonalitic to granodioritic rocks. This compositional heterogeneity can be also observed in the radiometric data, where each mapped unit shows different resolutions on $U$ and Th values (Figs. 2 and 3). Intermediate values of $\mathrm{Th}$, expressed in red color, are constrained with low values in blue and reflect compositional diversity in the basement rock. Alternance of bands with distinct radiometric intensity represents the compositional variation of basement rocks, where the most primitive geochemical nature of tonalite, gabbro and diorite is indicated by low Th, $\mathrm{U}$ and $\mathrm{K}$ values, and more granitic composition, by intermediary radiometric values (displayed as numbers 1, 2, 3 and 4 in the Figure 5). The mapped geophysical signatures suggest a geological architecture consistent with that of a zoned batholith, showing an inward increase in $\mathrm{K}$, $\mathrm{U}$ and $\mathrm{Th}$ values, as suggested by the geochemical and mapping studies of Hackspacher et al. (1990). Ratios of eTh and eU maps are a good manner to enhance this zoned pattern. Insight on the zoned pattern of basement rocks with similar behavior are described for some granite rocks in the western Canadian Shield (Schetselaar 2001).

Tectonic lineament, folds and superposed strucutural trends Despite the fact that aeromagnetic data are still the best way to discriminate structural features, gamma-ray spectrometry turned out to be also an excellent tool to distinguish different superposed tectonic events overprinted in the rocks, at least as far as their surface signatures is concerned. Thus, the radiometric data are able to identify regional and more detailed scale structures. The 
displacement of the main NE trending structures to W-E trending in the central part of the Seridó belt is caused by the widespread branching system of transcurrent shear zones, and is evident in the southern part of the studied area (Patos lineament). Precise definition of the boundaries between the Serido schist and the basement rocks (Picuí-João Camara Shear zone) can also be seen. The dextral shear sense of this structure could be determined (Figs. 2,3 and 4).

Spatial analysis of the Th channel turns possible the individualization of different tectonic domains in the Serido belt, the Caicó block in the southwestern part and the Lajes block in the northern part. The domain boundaries coincide with abrupt changes in structural trends. Geometry and contacts of granite bodies and faults are characterized by abrupt contrast between high and low intensity anomalies in narrow and straight linear belts, parallel to regional trend and foliation.

A predominant NW trend of the structures in the Caicó region is evident, mainly in the Th channel data and in the ternary image data (Figs. 5 and 7). Another important enhanced feature is the bending of the NW to NE trending structures caused by the large ductile transcurrent shear zones in this region. It is possible to discern the dextral sense movement of the shear zone and several complex fold interference patterns caused by superposed structural trends related to different orogenic events. The youngest NE trend structures are continuous, rotated and cross cut the oldest, NW trending structures, then displacing. However, NW trending, strikeslip shear zones could also be developed contemporaneously with the NE direction (Araújo et al. 2002).

Large-scale folding and ductile shear zones are well defined in the Th and U channel images (Figs. 3 and 4) as in the Lages and Caicó regions. Folds are open to recumbent, identified by their anomalies shapes by the increase in thickness and parallel symmetry of its limbs.

Regional mapping units The RGB model image (Fig. 7) contains colors generated from the relative radiometric intensities for the three components and represents subtle variations in the ratios over the three bands. Also, the RGB image turned out to be the best achieved product to visualize each lithological unit from the specific geophysical signatures. The interpretation from these images is represent in Figure 8.

The precise individualization of the round shapes of the two granite bodies intruded in the metasedimentary sequence of Seridó Schist (the Acari and Cardozo plutons) is straightforward. Their signatures come from the high $\mathrm{K}, \mathrm{U}$ and $\mathrm{Th}$ values which combine in the composition to give a white color. Also, high $\mathrm{K}$, Th and $\mathrm{U}$ content of these granites is in agreement with the enriched $\mathrm{Nd}$ isotopic signature they present, suggesting a source rock derived from a predominantly reworked continental crust (Dantas 1998).

The abrupt contact between the Acari Pluton and its host rocks is evident in this ternary image, as well as their different mapped petrographic potassium poor and rich facies, enhanced by the difference in the RBG composite color intensity. This feature is also recognized in the $\mathrm{Th}$ channel and $\mathrm{eTh} / \% \mathrm{~K}$ ratio grid.

Based on their different radiometric properties, each lithological assemblage could be identified as the occurrence of marbles, quartzites and amphibolites in the Jucurutu Formation. Quartzites from the Equador Formation could be distinguished by their high potassium content (Fig. 7).

On the other hand, amphibolites rocks from the Jucurutu Formation were recognized by their low radiometric values due to their primitive geochemical nature. The dominant epidote gneiss from the Jucurutu Formation also shows low U, Th and $\mathrm{K}$ values. Schists from the Seridó Formation were characterized by their medium to high $\mathrm{Th}$ and $\mathrm{U}$ values from their muscovite and biotite content. Thus, the metasedimentary rocks from Jucurutu and Seridó rocks present different pattern in the RBG image and could be easily separated and mapped. The Tertiary sedimentary covers in the Serra de Santana region, and in the central part of the Seridó Belt, display low $\mathrm{K}$, Th and $\mathrm{U}$ signatures and are characterized by showing a black color in RGB map (feature F in Figure 7).

The radiometric ratio images tend to remove the effect of the lithological differences and those from the variations in soil moisture, non-planar source geometry, and errors associated with altitude correction. According to Darnley (1972), lithological differences tend to be removed because radioelement concentrations frequently vary with lithologic changes. The eU/ $\mathrm{eTh}, \mathrm{eU} / \mathrm{K}$ were useful for determining important lithological changes and contacts.

The basement rocks of the area can be separated into three major crustal blocks from their different isotopic $\mathrm{Nd}$ signatures (Caicó, Lages and Santa Cruz blocks in Figure 7; Dantas,1998). The same can be done from the airborne geophysical data, which reveal distinctive geochemical and petrogenetic variations (medium to high-K) within the calc-alkaline rocks that compose this region (Figs. 7 and 8).

DISCUSSIONS AND CONCLUSIONS The first airborne gamma-ray spectrometer surveys were flown almost 40 years ago (Grasty et al. 1997). However, it was only within the last five to ten years that airborne gamma ray spectrometry has become accepted as a useful tool not only for uranium exploration but also for geological mapping and mineral exploration. To a large extent, this is due to the improvement on the techniques for acquisition, calibration and processing of the airborne data. The increasing use of gamma-ray spectrometry over the past decade indicates that it will play even a more important role in geological mapping and mineral exploration in the future (Darnley et al. 1987, Grasty et al. 1997, Minty et al. 1997).

This paper discusses the importance of the airborne gamma-ray spectrometry in the geological mapping of the Seridó region, NE of Brazil. The three radiometric maps (showing the channels corresponding to the potassium, uranium and thorium signatures) were individually enhanced and then displayed in pseudo-color composition (R: B: G=K: U: Th). There is an obvious relationship between some mapped geologic units and the radiometric data. Individual lithological units can be traced due to their distinctive radiometric signatures. The difference observed in the basement rocks shows that reprocessing available data like this can provide a cost-effective definition of structures and lithologies in a complex geological terrane.

Considering the limitations of the geophysical data used and, specially, on what concerns to the technical conditions in which they it were collected (low resolution due to small crystal volume copped with old gamma-spectrometer electronic design, large sampling line separation etc), and the handicap they have when compared with present surveys, the obtained results are well compatible and could be compared also well with the 1:250 000 and 1: 100000 scale geological maps (Fig. 8). Integrated products of geophysical and other methods as isotope geochronology and geochemistry, are important for the individualization of tectonic domains and the cartography of different stratigraphic units in 


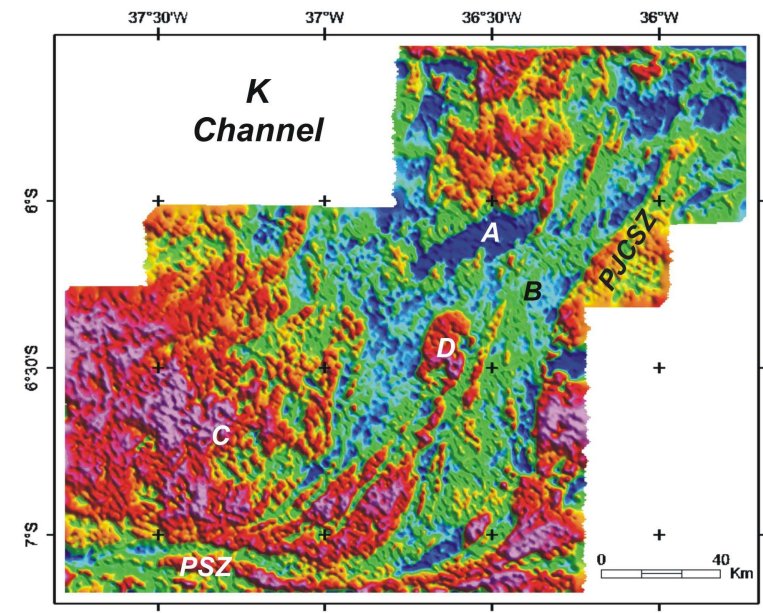

Figure 2 - Potassium image for the Seridó Belt after microlevelling. (A) Phanerozoic cover, (B) Neoproterozoic metasedimentary sequence, (C) Paleoproterozoic basement rocks and (D) granitoids plutons. Shear zones: PSZ - Patos, PJC SZ - Picui João Câmara.



Figure 4 - Uranium image for the Seridó Belt after microlevelling (A) Phanerozoic cover, (B) Neoproterozoic metasedimentary sequence, (C) Paleoproterozoic basement and (D) granitoids plutons. Shear Zones: PSZ-Patos, PJC SZ-Picuí João Câmara Shear

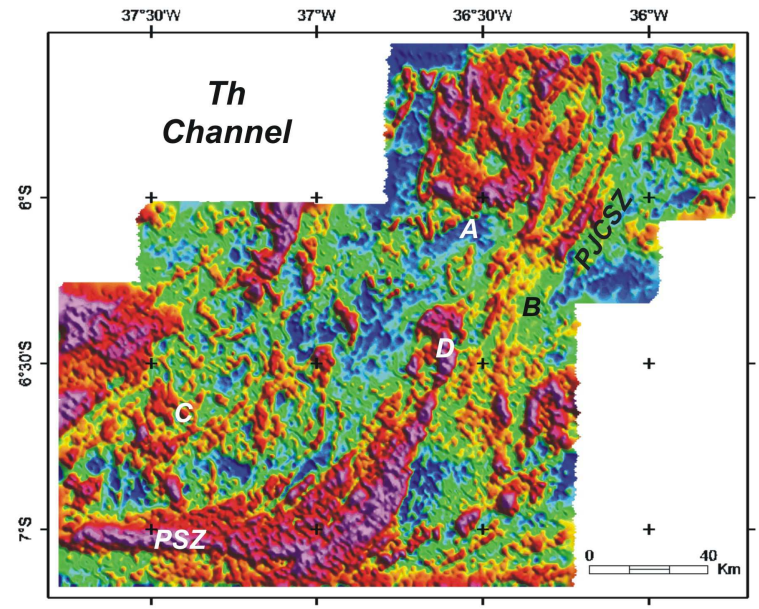

Figure 3 - Thorium image for the Seridó Belt after microlevelling (A) Phanerozoic cover, (B) Neoproterozoic metasedimentary sequence, (C) Paleoproterozoic basement and (D) granitoid plutons. Shear zones: PSZ - Patos, PJC SZ-Picui João Câmara.

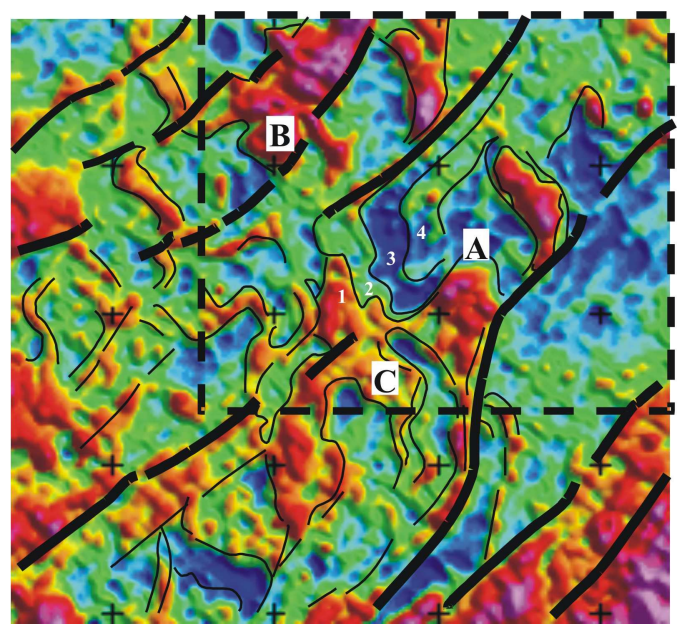

Figure 5 - Detail of Th channel of the Caico region. Several features are clearer when compared to the map of Fig. 6. (A) Different colors of the radiometric data reflect the mapped magmatic facies; (B) NE trending structures related to the main dextral strike slip shear zones rotating the $N W$ trending structures and (C) Large scale folds with complex interferences.
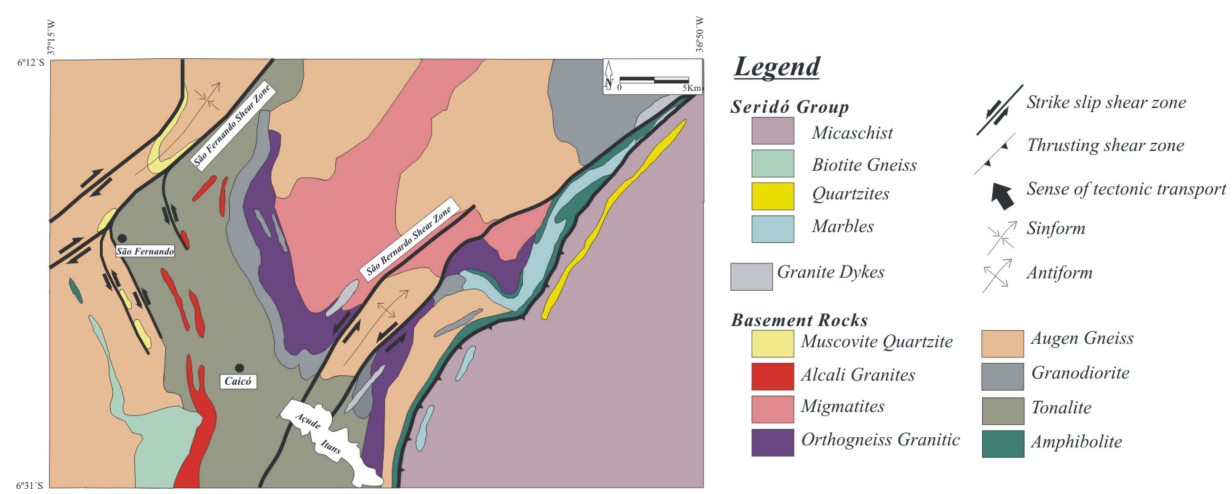

Figure 6 - Geological map from the Caicó region. (Modified from Hackspacher et al.s1990). Observe the compositional variation between tonalities, granodiorites and granites in the portion north of Caicó. 


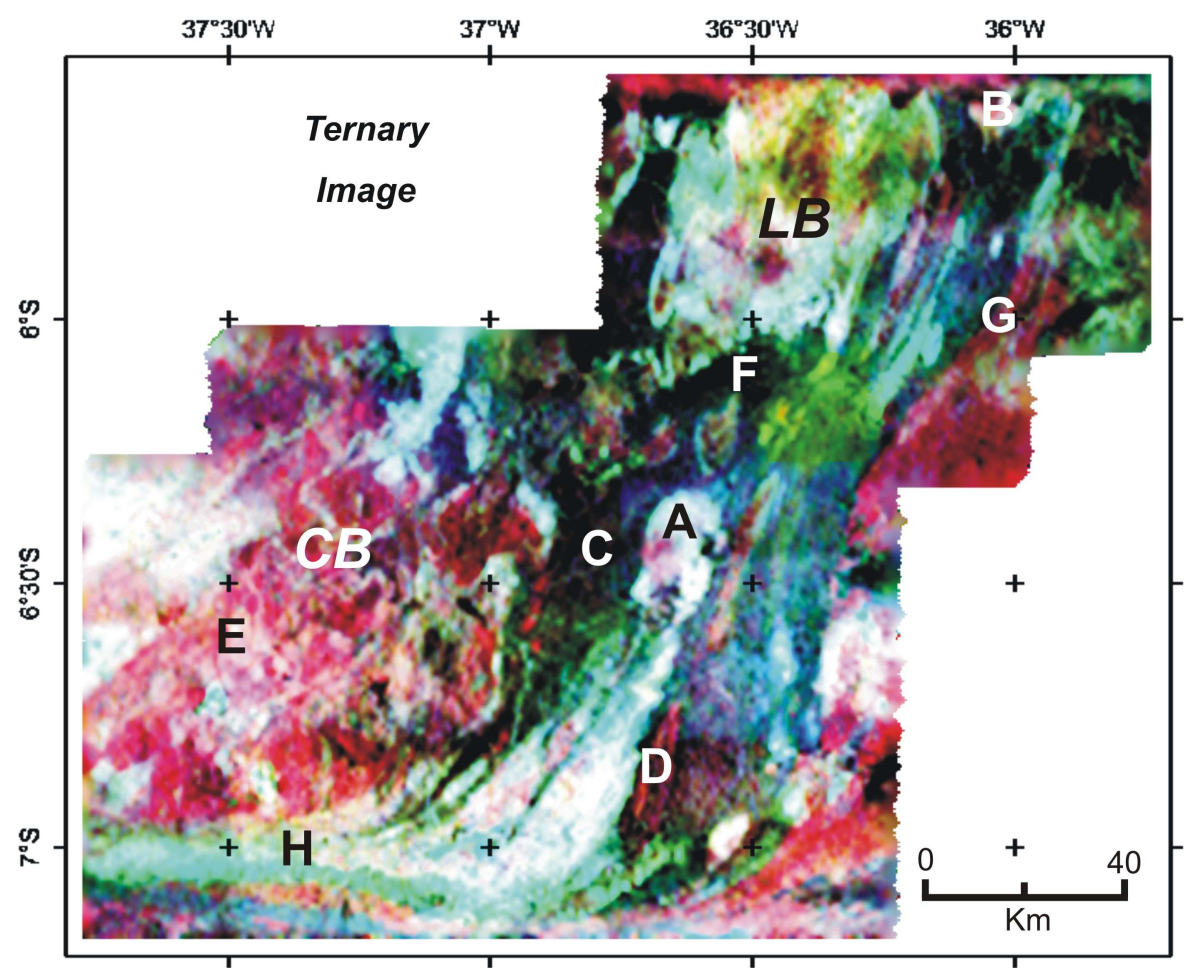

Figure 7 - Gamma-ray spectrometry image $(R G B=K T h U)$ for the Seridó Belt. A-Acari pluton, B-Cardoso pluton, C-Marbles (Jucurutu Formation), D-Quartzites (Equador Fm.), E-Basement rocks, F-Phanerozoic Cover, G-Picuí Shear Zone, H-Patos Lineament, CB-Caicó Block, LB - Lages Block.

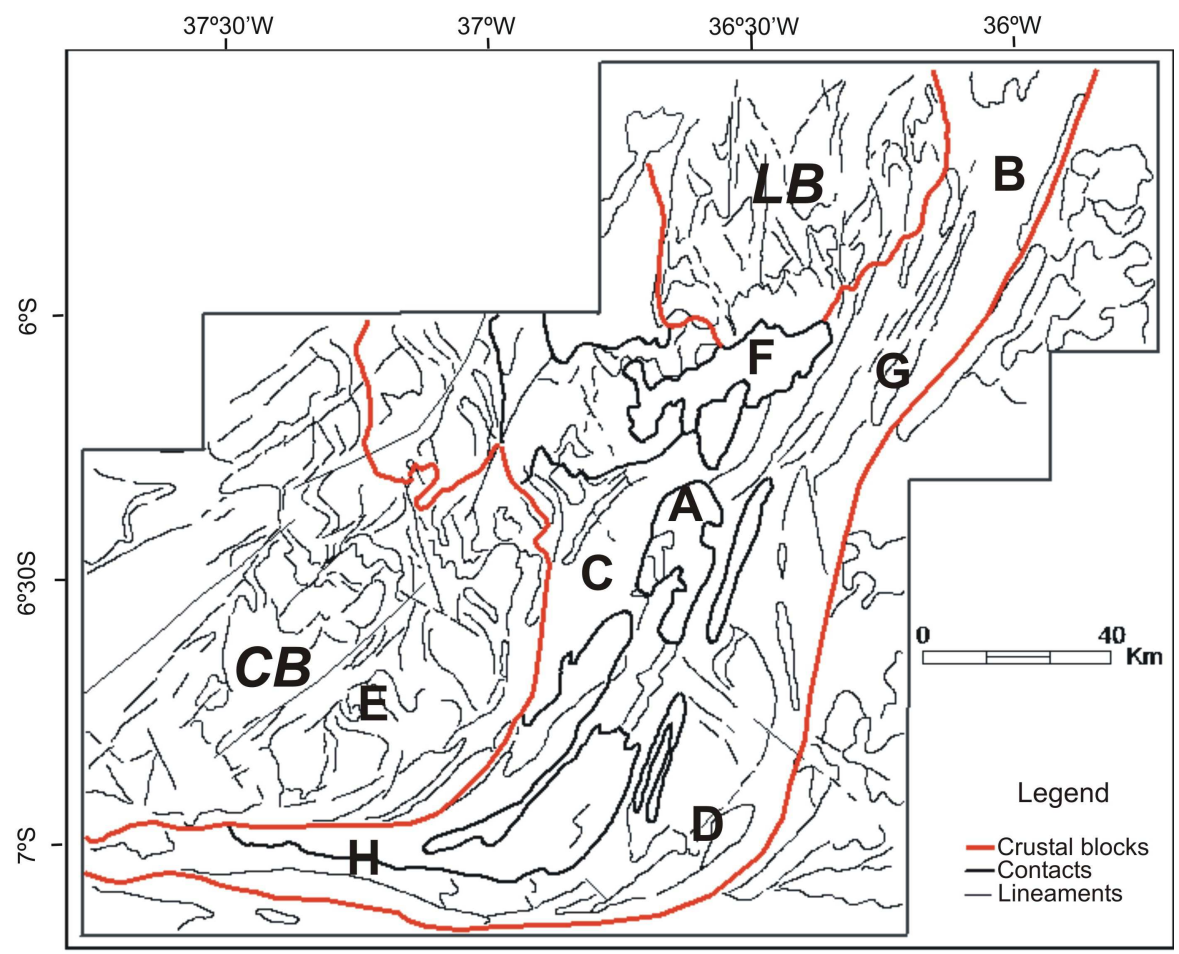

Figure 8 - Main geological and structural features of the Serido Belt obtained by the gamma-ray spectrometry data. The legend is the same of Figure 7. 
complex Precambrian terrains. The geophysical data could help in better understanding regional geology.

Several geological features of the Seridó belt that were enhanced by geophysical data include: a) Patos shear zone is a major tectonic lineament separating distinct litho-stratigraphic terrains; large lineaments are represented by abrupt change in the radiometric anomalies, marking the constraint between different tectonic domains; b) the Seridó supracrustal sequence occurs as a linear belt, NE trending, has over $100 \mathrm{~km}$ width and its different lithologic units can be individualized through airborne geophysical data; c) a remarkable magmatism is recorded by complex plutons with distinct geochemistry signatures; d) compositional variations with $\mathrm{SiO}_{2}$ content in the basement rocks are in agreement with different magmatic pulses and the geochemical data already described in the Caicó area; e) it should be interesting also to emphasize the use of the geophysical data to recognize overprinted and superposed features and structural trends, through the detailed interpretation of small-scale anomalies in the radiometric data.

The association between biotite with Th and/or U gamma-ray response is significant for granites and micaschists from the Seridó Formation. The Th data have shown to be the best product to distinguish structural features, because it is a stable element during soil formation and weathering process active in this region. As for tropical regions, probable this element is leached (Dickson \& Scott 1997). Several external factors as humidity, vegetation, and topography can affect the interpretation of the radiometric data (Schetselaar 2001), although these points were not considered in the present discussion.

Since a large airborne gamma-ray spectrometric database already exists, covering many parts of the Brazilian territory, it may be possible to use it, as it was done here, in order to gain a better understanding on the geology of poorly studied or inaccessible regions of the country. However, the most important consideration on the interpretation of airborne geophysical data is to keep in mind the regional geological context and the basic relationships between the studied rocks.

Acknowledgments To CPRM (Brazilian Geological Survey) for permission to use the radiometric data for this research, Dr. Marcelo Lawrence de Bassay Blum for the help in data processing, Dr. Allen Fetter and to the RBG reviewers for suggestions to the manuscript.

\section{References}

Araújo M. N. C., Alves da Silva F. C., Jardim de Sá E. F., Holcombe R. J., 2002. Geometry and Structural Control of $\mathrm{Au}$ Mineralizations in Seridó Belt, NE Brazil. J. South Am. Earth Sci., 15:337-348.

Archanjo C.J., Trindade R.I., Bouchez J.L., Ernesto M. 2002. Granite fabrics and regional-scale strain partitioning in the Serido Belt (Borborema Province, NE Brazil). Tectonics, 21 (1):1-13.

Briggs I.C. 1974. Machine contouring using minimum curvature. Geophysics, 39 (1): 39-48.

Blum M.L.B. 1999. Processamento e interpretação de dados de geofisica aérea no Brasil central e sua aplicação à geologia regional e prospecção mineral. Instituto de Geociências. Universidade de Brasília. Tese de Doutorado, 229p.

Castro D.L., Medeiros W.E., Jardim de Sá E.F., Moreira, J.A.M. 1998. Gravity map of part of northeast Brazil and adjacent continental margin and its interpretation based on hypothesis of isostasy. Rev. Bras. Geof., 16:115-132.

Costa L.T.R., Vale A.G., Silva A.M. 2002. Interpretação de dados aerogeofísicos e imagens de sensores remotos como ferramenta para o mapeamento geológico na região nordeste do Cráton Amazônico: $\mathrm{O}$ exemplo do Projeto Promin-Renca. In: E.L. Klein, M.L. Vasquez, Costa L.T. R. (eds). Contribuições à Geologia da Amazônia, Belém, V3: 227-244.

Companhia de Pesquisa de Recursos Minerais (CPRM). 1995. Catálogo geral de produtos esServiços. Geologia. Levantamentos aerogeofisicos. Base de Dados AERO. 2a. Ed., Rio de Janeiro, RJ, Diretoria de Geologia e Recursos Hídricos.

Dantas E.L., Hackspacher P.C., Van Schmus W.R., Brito Neves B.B., Wernick E., Magini C., Legrand J.M., Petta R.A. 2001. Novos dados Sm-Nd do embasamento Paleoproterozóico do Terreno Rio Grande do Norte: implicações petrognéticas e tectônicas. In: SBG, SNET, 7, Recife, 55-58

Dantas E.L. 1998. Geocronologia U-Pb e Sm-Nd de terrenos arqueanos e paleoproterozóicos do Maciço Caldas Brandão, NE do Brasil.
Tese deDdoutorado, UNESP, Rio Claro - SP.

Darnley A.G. 1972. Airborne gamma-ray survey techniques. In: S.H. Bowie, M. Davis, D. Ostle (Ed)Uranium prospecting handbook. London, The Institute of Mining and Metallurgy, pp. 174-211.

Dickson B.L. \& Scott K.M. 1997. Interpretation of aerial gamma-ray surveys-adding the geochemical factors. AGSO, J. Astral. Geol. Geoph., 17:187-200.

Direen N. G., Lyons P., Korsch, Glen R.A. 2001. Integrated geophysical appraisal of crustal architecture in the eastern Lachlan Orogen. Exploration Geophysics, 32:252-262.

Golysky A. \& Jacobs J. 2001. Greenville-age versus Pan-African Magnetic Anomaly Imprints in Western Dronning Maud Land, East Antarctica. The Journal of Geology, 109:136-142.

Gunn P.J., Minty B. R. S., Milligan P. R. 1997. The airborne gamma-ray spectrometric response over arid Australian Terrenes. In: A.G. Gubins (Ed) Geophysics and Geochemistry at the millennium. Proceedings of the fourth decennial International Conference on Mineral Exploration, 733-740.

Hackspacher P. C., Dantas E. L, Magini C. 1992. O batólito São VicenteCaicó-RN. In: SBG, Cong. Bras. Geologia, São Paulo, 2:143-144.

Hackspacher P.C., Van Schmus W.R., Dantas E.L. 1990, Um embasamento tranzamazônico na Província Borborema, In: SBG, Cong. Bras. Geol., 36, Anais, pp. 1683-2696.

Jaques A.L., Wellman P., Whitaker A., Wyborn D. 1997. High-resolution geophysics in modern geological mapping. AGSO, Journal of Astralian Geology \& Geophysics, 17 (2): 159-173.

Jardim de Sá E.F. 1994. A Faixa Seridó (Província Borborema, NE do Brasil) e o seu significado geodinâmico na cadeia Brasiliana/PanAfricana. Tese de Doutorado, UnB, Brasília - DF.

Minty B. R. S., 1991, Simple Micro-leveling for aeromagnetic data. Exploration Geophysics, 22: 591-592.

Minty B R S. 1997. Fundamentals of airborne gamma-ray spectrometry. 
AGSO, J. Austral. Geol. Geoph., 17:39-50.

Oliveira R.G., Santos E.J., Silva Jr. J. M., Lines C.A.C. 2001. Magnetic, gravity and gamma-ray spectrometry responses of tectonostratigraphic terrenes in the Jaguaribe-SE sheet (SB24Z), Northeastern Brazil, 7 CSIBGf/PS.

Reeves C. V., Reford S. W., Millingan P.R. 1997. Airborne geophysics: old methods, new images. In: Gubins, A.G. (ed), Geophysics and Geochemistry at the millennium. Proceedings of the Fourth Decennial International Conference on Mineral Exploration, 13-30.

Santos E.J., Van Schmus W.R., Brito Neves B.B., Oliveira R.G., Medeiros V. 1999. Terrenes and their boundaries in the Proterozoic Borborema Province, NE Brazil. In: SBG, SNET, 7, Lençois, Bahia, Anais, pp. 121-124.

Schetselaar E.M. 2001. Petrogenetic interpretation from gamma-ray spectrometry and geological data: The Arch Lake zoned peraluminous granite intrusion. Western Canadian Shield. Exploration Geophysics, 33:35-43.

Silva A.M. 1999. Integração de dados geológicos e geofisicos utilizando- se uma nova técnica estatística para a seleção de alvos para exploração mineral, aplicada ao Greenstone Belt Rio das Velhas, Quadrilátero Ferrifero. Instituto de Geociências. Universidade de Brasília. Tese de Doutoramento. 195p.

Souza M.G. 2000, Aeromagnetometria e sensoriamento remoto da Faixa Seridó-RN: aplicações em tectônica e em controle de depósitos. Dissertação de Mestrado.Universidade Federal do Rio Grande do Norte, $119 \mathrm{p}$.

Van Schmus W.R., Brito Neves B.B., Hackspacher P.C., Babinski M. 1995. $\mathrm{U} / \mathrm{Pb}$ and $\mathrm{Sm} / \mathrm{Nd}$ geocronological studies of the eastern Borborema Province, northeastern Brazil: initial conclusions. J. South Am. Earth Sciences, 8:267-288.
Manuscrito SR-08

Recebido em 30 de agosto de 2002

Revisão dos autores em 25 de março de 2003 Revisão aceita em 21 de abril de 2003 